\title{
CRIME IN FOREIGN ECONOMIC SPHERE IN THE POST-SOVIET STATES
}

\author{
Yevhen Hrechyn ${ }^{1}$, Vasyl Burba ${ }^{2}$
}

\begin{abstract}
The purpose of the article is to reveal the content of organized crime in foreign economic sphere and the factors that determine the state and trends of its development. It is revealed the influence of corruption as a form of organized crime on foreign economic activity, which is illustrated by examples of illegal actions in this area. It is concluded that organized crime in foreign economic sphere essentially goes beyond the limits of the customs regime violations, evasion of customs duties and other payments and threatens the functioning of the whole sectors of post-Soviet countries' economies. Methodology. The study is based on the economic and criminological approaches developed by J. Knorih (Knorich, 2004), as well as S. Zedeg and N. Gustavson (Susanna Thedeg, 2009; Susanna Thede, 2012). It should also be noted the studies conducted by experts from international organizations such as the World Bank (S. J. Hellman, 2000), Transparency International (Transparency and Corruption, 2016) and the Organization for Economic Cooperation and Development (Quantitative Evidence on Transparency in Regional Trade Agreements, 2013). The consideration of issues related to the criminalization of foreign economic relations is based on the methods described in the works of J. Cassar (Cassara, 2015), K. Nordstrom (Nordstrom, 2007), M. Naim (Naim, 2006) and P. Shadri (Chaudhry, 2007), as well as in the author's works on countering corruption and organized crime (Hrechyn, 2015). Result of the study reveals the essence of crime in the foreign economic sphere as a form of corruption that poses threat to the economic security in post-Soviet states. This will allow us to assess the scale of the problem and evaluate appropriate responses.
\end{abstract}

Key words: foreign economic sphere, corruption, legalization of illicit gains, organized crime.

JEL Classification: A14, F20, H26, K42

\section{Introduction}

Investigation of offenses in the sphere of foreign economic activity mainly focuses on the issues of the impact of corruption on customs authorities activities and the certain offences committing such as excisable goods smuggling, evasion of customs duties and payments. In our study, we aim to disclose the essence of this criminal activity in the context of economic security ensuring in former Soviet Republics.

Our developments point to the need to reveal the multilevel effects of corruption and foreign economic relations and, through it, on the economy of the state as a whole. Studies conducted so far do not reveal this problem in its entirety. Moreover, the conclusions drawn from the results of these studies give the impression that the decriminalization of foreign economic sphere is possible through the mere reduction of corruption in customs authorities, which, in our opinion, does not correspond to the reality and does not take into account the multilevel and multidisciplinary nature of this problem.

\footnotetext{
Corresponding author:

${ }^{1}$ National Academy of the Security Service of Ukraine, Ukraine.

E-mail: ap0091994@gmail.com

${ }^{2}$ National Academy of the Security Service of Ukraine, Ukraine.

E-mail: ap0091994@gmail.com
}

International trade covers a wide range of relations, including the receipt and processing of raw materials, production of goods, various types of financial transactions that take place outside the customs border, affect the functioning of the economy as a whole and are vulnerable to corruption. Thus, the definition of customs authorities corruption level will not provide a complete picture of the illegal activities in this area, and the reduction of corruption risks in the customs authorities will have only a limited result for foreign economic relations decriminalization.

In the given study corruption is considered wider than the traditional approach that interprets it as a form of office abuse. We consider this phenomenon as a form of organized crime that covers a wide range of relations in the field of economy, politics and life of society as a whole, is connected with the criminality intended to influence the economy with the use of administrative power capabilities. We are talking about the integration of criminality, corrupt representatives of government and private sector, the aim of which is the use of illegal methods for personal enrichment. 


\section{Impact of corruption on in the foreign trade}

In post-Soviet space, organized crime is an alliance of the state, market and criminality, i.e. the political, business and criminal entity (Kupatadze, 2012). There is state seizure by organized crime, where the main players are oligarchs (Iwasaki, 2007). In countries where such seizure is carried out by a political or business elite, it is formed the so-called "entrenched economy", in which officials and politicians privately sell public goods and opportunities to receive rent for individual firms (Hellman, 2000). In some cases, the relationships between criminality and officials are so tight that we can talk about "kleptocratic interdependence", which is a set of ties that operate at the national and international levels, motivated by material benefits and power. In itself, such relationships are not something new, but in the context of globalization they begin to influence a wide range of security issues in the field of politics and economics (Greenhill). Therefore, anti-corruption measures here should be aimed primarily at the destruction of systemic links between criminality and government, rather than at identifying and prosecuting certain corrupt officers.

The spread of corruption in the foreign economic sphere forms a peculiar status of the country, which is taken into account by foreign actors when conducting business. As follows from the study by T. Soureyd, regardless of the corruption level in the country of origin the company treats corruption in the host country as one of the game rules that allows it to participate in corruption transactions, when large firms more often face greater corruption and state seizure and smaller firms - administrative corruption. The interdependence between the size of firms and the type of corruption is determined by the value of contracts that are concluded by the firms and the ability of the latter to reach a certain level of problems solving that accompany the conclusion and execution of contracts (Soreide, 2006).

Criminalization of the economy leads to a blurring of the boundary between legal and illegal, creating a situation in which illegal economy serves as a source of finance for a significant part of the population (Development Responses to Organized Crime, 2015). This, in turn, leads to a spread of criminal practices in all areas of public relations, distortion of the basic norms of the society.

In the context of economic relations, Transparency International proposes to consider corruption as a phenomenon that impedes trade and is a kind of illegal tariff (Transparency and Corruption, 2016). Studies indicate that the level of transparency in regional trade agreements increases bilateral trade by $1 \%$ (Iza Lejárraga, 2013). According to the EU estimates the region's economic losses from corruption amounted to 120 billion euros per year, which is almost equal to the annual budget of the European Union (EU AntiCorruption Report, 2014). According to a study by the
EU Center for Economic Policy Research (Reducing Transatlantic Barriers to Trade and Investment, 2013), the potential benefits from the Transatlantic Free Trade Agreement conclusion will number a similar amount each year. That is, measures to ensure transparency and good governance in the field of business and international trade are just as important from an economic point of view as conclusion of large-scale trade agreements (Transparency and Corruption, 2016).

On the other hand, conducted studies confirm that the liberalization of foreign trade can contribute to reducing the corruption level in post-Soviet countries and improving the quality of governance in general (Dutt, 2009). It is well-known that corruption is one of the factors that undermine free trade. Studies indicate that the impact of corruption is stronger for exporting countries than for importers of certain goods or services. Instead, corruption in the foreign economic sphere contributes to increasing imports to a corrupt country, creating shadow supply channels for this (Eelke de Jong, 2011).

At the same time, the Doing Business study 2017 concludes that a high level of international trade is also directly related to the low level of corruption in the country (Doing Business 2017, 2017).

Foreign trade is extremely important for the economies of former Soviet Republics in general and Ukraine in particular, the total import and export of which make up 108\% of GDP (2017 Index of Economic Freedom). At the same time, the level of foreign economic sector criminalization remains extremely high and corruption remains the main obstacle to business in the given states (The Global Competitiveness Report 2016-2017, 2016).

According to the World Bank study, post-Soviet states need to improve foreign economic sector by building more productive private sector and forming more complex export structure with a higher value added. In the experts opinion it is hampered by infrastructure weakness, market structure characterized by a high level of concentration and monopolization, as well as weak land management. Infrastructure improving involves strengthening the opportunities for domestic investment and improving the management system and ensuring transparency (Ukraine. Systematic Country Diagnostic Toward Sustainable Recovery and Shared Prosperity, 2017).

There are a number of schemes that are used by the foreign economic activity subjects to avoid taxation. All of them include the involvement of corrupt state authorities' representatives.

For example, an exporter resident achieves a tacit agreement with a foreign company - the recipient of the goods for a contract at a pre-overstated price. In particular, the amount of advance payments is increased and fictitious prepayments for transactions are made. Then the buyer pays half the difference between the contract price and the real value of the goods.

The simplest shadow scheme is the registration of the inventory items acquisition from fictitious firms 
and their export to distant states and territories. In fact, the movement of such values, transportation and crossing the border do not occur, contractual and import relations with country's residents do not exist. The calculations are simulated through commercial banks specializing in conversion services (using bill schemes, etc.). The role of intermediaries is given to enterprises in underdeveloped countries. The outlined mechanisms are primarily used by large enterprises, foreign economic activity subjects, especially those that constantly import goods, since these operations allow repayment of the obligation to pay "import" VAT with a fictitious tax credit.

It is also widespread the scheme of price increase at the expense of the cost of fictitious production (for example, receiving the components from fake companies), in which the producer enterprise is declared bankrupt and liquidated before the beginning of export operations. As a result, VAT is refunded directly and the account is made through a tax bill when performing import operations.

The scheme is implemented through the use of banking tools. The same bank serves all the basic calculations in the process of its implementation, allocates credit resources, emits securities (operations to provide and repay loans, in relation to bank securities is an integral part of the financial mechanism), provides currency calculations. Only an insignificant part of the transaction volume, which is usually equal to the amount of illegal profits, is separated and passed through another bank institution - the partner of the main bank. The whole chain of financial calculations is realized within one day. The specified mechanism is controlled by one bank - the financial scheme operator. Such activity is systematic and, in fact, is considered as a kind of banking service.

When applying this scheme, the exported goods are subsequently returned to the territory of the particular country and sold at prices ten times lower than the export price. Then the goods are legalized overpriced through fake and transit firms and used in the re-export scheme.

Criminally gained income is converted into cash and distributed among the participants of the scheme. The balance is transferred to the account of the goods importer, from where it is returned as the official revenues for the exported goods.

According to another scheme, for example, nickel allegedly for processing was imported in the particular country as a toll-free raw material, which after was sold on the domestic market through a network of specially created fake companies. Such import involved the receiving by the importer of a license for processing, which he really could not carry out due to lack of production capacity.

Since the raw material was imported as if it were exclusively for processing without realization on the territory of the country, the customs regime "import 54" was applied to it, in which the actual importer did not pay neither VAT (20\%) nor customs duties (13\%). In fact, concerning this operation the customs regime "import 40" should be applied which provides for such payments.

Subsequently, according to the given scheme, nonferrous scrap metal was illegally collected, in which also fictitious firms without appropriate license were involved. The purchase of metal was carried out on a black market, while the requirements regarding the source of origin of this raw material for obvious reasons to sellers were not put forward. Non-ferrous metals were being melted at the bastards, which were further exported under the guise of an imported nickel processing product. Herewith the export fee also was not paid.

Thus, the state not only lost the money that would have been paid when importing the metal for its processing and sale in the domestic market of the country. But nickel was sold at a dumping price that undermined free competition and damaged the entire metal processing industry. Non-ferrous metals necessary on the domestic market of the country were exported which also caused substantial damage to the state's economy. The black market of non-ferrous metals was strongly stimulated that contributed to their robbery and illicit circulation.

As a result of this and similar actions, there is a threat not only to the foreign economic sphere of post-Soviet states, but also to the economies of the states as a whole. Smuggling is only one of the components of this scheme. The leadership of the highest public authorities usually is involved in conducting such fraudulent actions. Instead, the role of corrupt customs officials is minimal and consists solely in assistance to accelerate import of nickel in the country, which does not have a critical importance for the implementation of this scheme.

Similar schemes are fixed not only in the metal processing, but also in the chemical industry and the agro-industrial sector.

One of the crime manifestations, closely related to corruption in the foreign economic sphere, is the illegal use of citizens for testing drugs that do not have appropriate license. Thus, in 2013, a scheme was discovered according to which new drugs being tested by the manufacturer on their efficacy and possible adverse effects were illegally imported into one of former Soviet Republics and subsequently tested on the patients who were not aware about the possible threat for their lives of receiving these drugs. The given operations provided for the existence of corrupt relations in the leadership of the state's customs and health authorities who received bribes from corporations for the use of the citizens for the testing drugs. At the same time, neither the patients nor the state budget of the country received any funds for such tests. It should be noted that in some cases, such tests were also conducted on juvenile patients on 


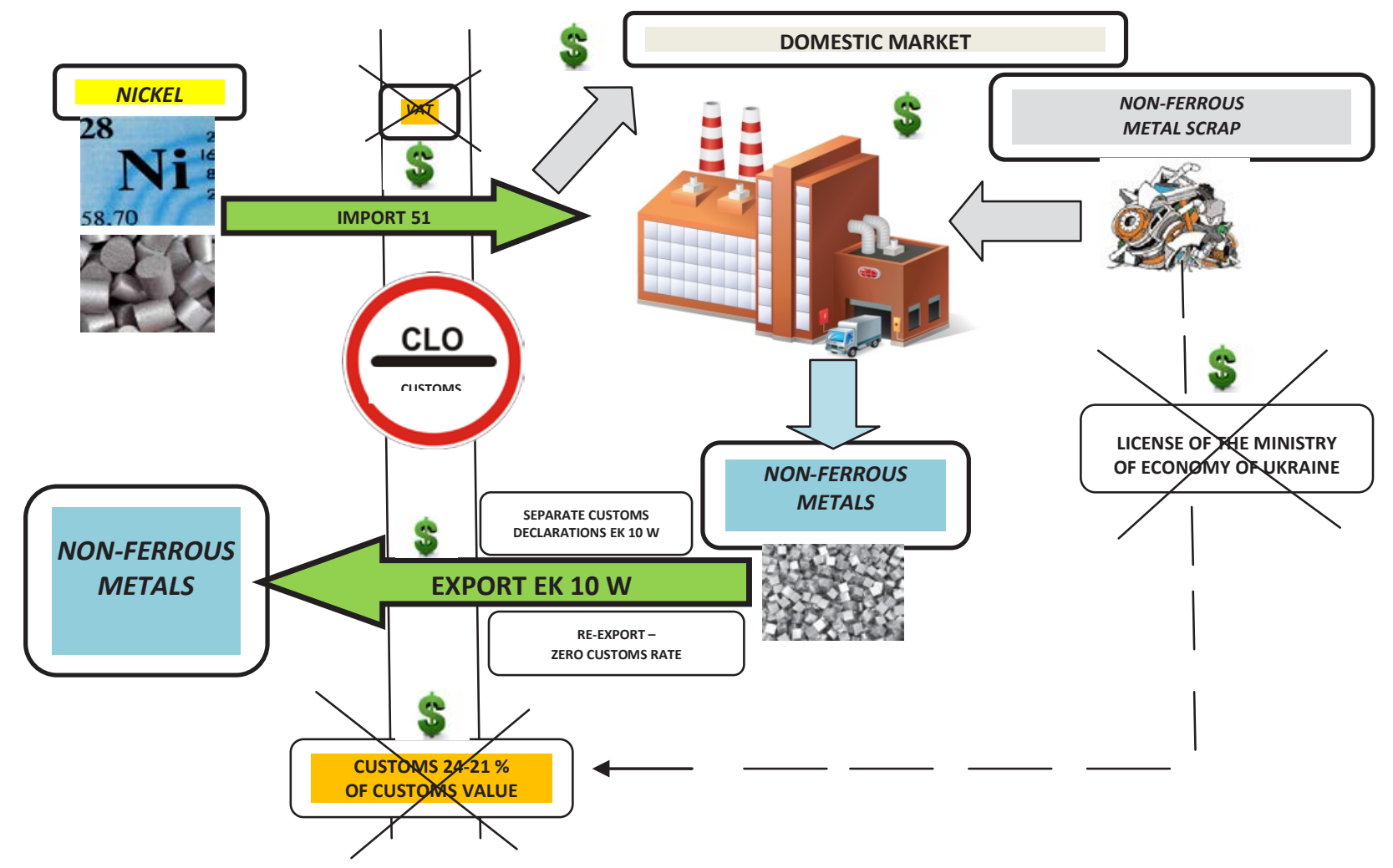

Figure 1. Smuggling scheme for the import of nickel and the export of non-ferrous metals

the basis of pediatric medical centers. The aforesaid points out, that corruption in foreign economic sphere threatens not only the economic potential of any postSoviet state, but also poses a direct threat to the life and health of its citizens, the gene pool of the whole nation.

\section{Findings}

The magnitude and extent of corruption in post-Soviet states have transformed this phenomenon into a major threat to their systems of national security. Corruption in the field of foreign economic activity is a particular threat, undermining the country's fiscal policy, forming a negative investment climate, which makes it impossible for the state to carry out any effective economic and social policy, destroys the image of the state in international relations. The weak effectiveness of anti-corruption measures in general and in the foreign economic sphere, in particular, is generally recognized. To a large extent, this is due to not only weak effectiveness of law enforcement measures, but also to the corrupt components laid down in the construction of this activity at the national level, the weakness of the institutional system of the state as a whole, as well as the inadequacy of anti-corruption policy to the current state of affairs. Such policy should take into account changes in the social nature of corruption crimes, the emergence of new corruption actors and the detection of previously unknown ways of committing them. Systemic corruption in transitional former Soviet countries is characterized by a combination of state seizure by a highly monopolized private sector or a strong bureaucracy, business seizure and administrative corruption.

\section{Conclusions}

The criminalization of the foreign economic sphere is caused by a wide range of factors, among which the internal ones prevail, which are connected with the institutionalization of corruption in the state authorities and administration. Criminal activity in this area is carried out by powerful corrupt and criminal organized mafia-type structures that are capable of controlling the whole spheres of economic and political life of the country, which have sufficient resources to influence public consciousness through controlled media. As a result of their activities, the state loses at least $50 \%$ of income related to the taxation of this economic activity. Conditions are created for smuggling of socially harmful goods, such as weapons, counterfeit medicines, drugs and psychotropic substances.

Such criminal activity has become systematic and one of the most acute threats to the national security of former Soviet Republics, undermining their economic development, depriving the budgets of funds necessary for the development of the states, the functioning of their institutions and social support of the population.

Taking into account the corruption risks existence and the degree of corruption threat for the economies, 
ensuring transparency in the functioning of the foreign economic systems of post-Soviet states should be considered as an absolute priority for anti-corruption measures. Countering corruption should be aimed at destroying the systemic relations between criminality and authorities and not limited to identifying and prosecuting certain corrupt officials. This in turn includes the involvement of civil society and international experts in the implementation of programs to ensure integrity in this area. The dissemination of anti-corruption measures to institutions in both the public and private sectors is also important.

\section{References:}

Knorich, Jan (2004). International trade and corruption: the influence of trading partners - Seton Hall University dissertations and theses. Retrieved from: http://scholarship.shu.edu/dissertations/682

International trade and the role of corruption. Susanna Thede, Nils-Åke Gustafson - European Trade Study. Retrieved from: www.etsg.org/ETSG2009/papers/thede.pdf

The multifaceted impact of corruption on international trade (2012). Susanna Thede, Nils-Åke Gustafson. The World Economy, 35(5), May 2012, 651-666.

Hellman, S. J., Jones, G., Kaufmann, D. (2000). Seize the state, seize the day: State capture, corruption, and influence in transition. World Bank Publications. 2000. Retrieved from: http://www.worldbank.icebox.ingenta.com/ content/wb/wps4301/2000/00000001/00000001/art02444

Transparency and corruption: a role in mega trade deals (2016). Transparency International. Working Paper.

Iza Lejárraga, Ben Shepherd (2013). Quantitative evidence on transparency in regional trade agreements. Trade Policy Paper no. 153. Paris: Organisation for economic co-operation and development.

Cassara, J. A. (2015). Trade-based money laundering: the next frontier in international money laundering enforcement - Wiley.

Nordstrom, C. (2007). Global outlaws: crime, money, and power in the contemporary world. University of California Press.

Naim, M. (2006). Illicit: How smugglers, traffickers, and copycats are hijacking the global economy. Anchor.

Chaudhry, P. E. (2017). Handbook of research on counterfeiting and illicit trade. Edward Elgar.

Hrechyn, Ye. Ye. (2015). Customs component of the national security of Ukraine: main factors and strategic priorities of development. Scientific Bulletin of the Security Service of Ukraine, 54, 11-21.

Hrechyn, Ye. Ye. (2015). Determination factors of corruption in customs bodies. Collection of scientific works of the Security Service of Ukraine, 54, 35-42.

Kupatadze, A. (2012). Organized Crime, political transitions and state formation in Post-Soviet Eurasia. Palgrave Macmillan.

Iwasaki, I., Suzuki, T. (2007). Transition strategy, corporate exploitation, and state capture: an empirical analysis of the former Soviet states. Communist and Post-communist Studies, 40(4), 393-422.

Hellman, S. J., Jones, G., Kaufmann, D. (2000). Seize the state, seize the day: State capture, corruption, and influence in transition. World Bank Publications. Retrieved from: http://www.worldbank.icebox.ingenta.com/content/wb/ wps4301/2000/00000001/00000001/art02444

Greenhill, K. M. Kleptocratic interdependence: trafficking, corruption, and the marriage of politics and illicit profits. Corruption, Global security, and world order / edited by Robert I. Rotberg. Washington, D. C.: Brookings Institution Press.

Soreide, T. (2006). Corruption in international business transactions: the perspective of Norwegian firms. International handbook on the economics of corruption / edited by Susan Rose-Ackerman. Massachusetts: Edward Elgar Publishing.

Development responses to organized crime: new agendas, new opportunities: a conference report. - Geneva: global initiative against transnational organized crime. November 2015.

EUAnti-Corruption Report. Reportfrom the Commission to the Counciland the European Parliament COM(2014) 38. - Brussels: European Commission, 2014. Retrieved from: http://ec.europa.eu/dgs/home-affairs/e-library/ documents/policies/organized-crimeand-human-trafficking/corruption/docs/acr_2014_en.pdf

Reducing Transatlantic barriers to trade and investment: an economic assessment. - London: Centre for Economic Policy Research, 2013. Retrieved from: http://trade.ec.europa.eu/doclib/docs/2013/march/tradoc_150737.pdf Dutt, P. (2009). Trade protection and bureaucratic corruption: an empirical investigation. Canadian Journal of Economics, 42(1), 155-183.

Eelke de Jong, Christian Bogmans (2011). Does corruption discourage international trade? European Journal of Political Economy, 27, 385-398.

Doing business 2017. Equal opportunity for all. International Bank for reconstruction and development. The World Bank. Terry Miller, Anthony B. Kim (2017). Index of Economic Freedom. Washington, DC: The Heritage Foundation. Klaus, Schwab (2016). The global competitiveness report 2016-2017. World Economic Forum.

Ukraine (2017). Systematic country diagnostic toward sustainable recovery and shared prosperity. World Bank Group, April 28. 